\title{
Nymphal and adult cephalic chaetotaxy of the Cydnidae (Hemiptera: Heteroptera), and its adaptive, taxonomic and phylogenetic significance
}

\author{
JERZY A. LIS ${ }^{1}$ and DoMINIQUe PLUOT-SIGWALT ${ }^{2}$ \\ ${ }^{1}$ Department of Biosystematics, Division of Zoology, University of Opole, Oleska 22, PL-45-052 Opole, Poland; \\ e-mail:cydnus@uni.opole.pl \\ ${ }^{2}$ Laboratoire de Biologie et Évolution des Insectes, École pratique des Hautes Études et Muséum National d'Histoire Naturelle, 45 \\ rue Buffon, F-75005 Paris, France; e-mail: dps@mnhn.fr
}

Key words. Hemiptera, Heteroptera, Cydnidae, morphology, cephalic chaetotaxy, primary setae, secondary setae, adults, nymphs, ontogenesis

\begin{abstract}
Cephalic chaetotaxy of nymphal and adult stages of species from all the subfamilies of Cydnidae s. str. (sensu Froeschner, 1960 and Lis, 1994), namely Garsauriinae, Cephalocteinae, Cydninae, Sehirinae, and Amnestinae, was studied. Two types of setae, primary and secondary, are described, and changes they undergo during ontogeny reviewed. The adaptive, taxonomic and phylogenetic significance of the cephalic setae in the Cydnidae s. str. is discussed. A ground-plan of the original cephalic chaetotaxy of the family, and its evolution within the family Cydnidae s. str. are proposed.
\end{abstract}

\section{INTRODUCTION}

The presence of different types of setae on the body margins is typical of Cydnidae, a family of Pentatomoidea that includes many species living on and in the soil. Different types of setae (often stout, sometimes even peg-like or spine-like) are present on the margins of the head, thorax, abdomen and always on the legs, particularly on the tibiae. Their function is still poorly understood, but are usually presumed to be tactile setae (mechanoreceptors) developed as an adaptation for burrowing (Froeschner, 1960; Dolling, 1981; Linnavuori, 1993).

Signoret (1881) was the first to use characters related to the types, number and distribution of setae (mainly cephalic) for the classification of Cydnidae; he was followed by Froeschner (1960), Dolling (1981), Linnavuori (1993) and Lis (1994). Moreover, certain characters connected with cephalic chaetotaxy were regarded as of generic importance within the Cydnidae (Froeschner, 1960; Linnavuori, 1993; Lis, 1994).

Cephalic setae in adults of burrower-bugs are distributed mainly on the margins of the paraclypei, and sometimes also on the anterior margin of the clypeus; thoracic setae are present on the lateral margins of the pronotum, as well as on the corial margins of the hemelytra, whereas the abdominal setae are on the lateral margins of the sterna. Unfortunately, the chaetotaxy of the nymphal stages of Cydnidae is almost unknown; to date, nymphs (or their body parts) of all but a few species were described or figured (see Table 1) usually without reference to their chaetotaxy (Kobayashi, 1964; Larivière, 1995; Linnavuori, 1993; Lis, 1992).

Although Cobben (1978) studied the cephalic chaetotaxy of nymphal and adult stages of numerous species from many heteropteran families, he concluded (op. cit., p. 61) that "there is no or hardly any ontogentic change in the cephalic sensory setae, but only phylogenetic disap- pearance". However, during preliminary studies on the nymphal development of Cydnidae bred in the laboratory and preserved specimens, we noticed differences in the patterns of cephalic chaetotaxy of nymphal and adult stages. This was mentioned previously by Linnavuori (1993), who reported the loss of cephalic spines in adults of two species of Cydnidae, namely Geotomus hirtipes (Palisot de Beauvois) and Geocnethus pallipennis (Dallas).

The present study attempts to explain this phenomenon in Cydnidae, using more extensive material, and the value of cephalic chaetotaxy in the classification of the family.

\section{MATERIAL AND METHODS}

Material. This study was based on living specimens collected in Senegal by the second author, and reared in the laboratory, as well as preserved museum specimens from the collections of the Laboratoire d'Entomologie, Muséum National d'Histoire Naturelle, Paris, France (MNHN), and the Department of Biosystematics, Division of Zoology, University of Opole, Opole, Poland (DBUO).

List of species and stages studied (nymphal instars [N1 to N5] and adult $[\mathrm{A}]$ ), and origin of specimens:

Garsauriinae

1. Garsauria laosana J.A. Lis, 1991 [N5, A, Vietnam, MNHN, DBUO];

Cephalocteinae (Scaptocorini)

2. Scaptocoris australis J.A. Lis, 1999 [N5, A, Australia, DBUO];

3. Stibaropus pseudominor J.A. Lis, 1991 [N1-N5, A, Malaysia, MNHN, DBUO];

4. Pseudostibaropus testaceus (Walker, 1867) [N5, A, India, DBUO];

Cydninae (Cydnini)

5. Cydnus aterrimus (Forster, 1771) [N5, A, France, Poland, MNHN, DBUO]; 


\begin{tabular}{|c|c|c|}
\hline Taxon & Source & Stage and body part studied \\
\hline \multicolumn{3}{|l|}{ Amnestinae } \\
\hline \multirow[t]{3}{*}{ Amnestus sp. } & Froeschner, 1960 & N2-N5 (head, descr., no figures) \\
\hline & Schaefer, 1975 & N2 (sternal trichobothria) \\
\hline & Thomas, 1988 & $\begin{array}{l}\text { N5 (descr., habitus), fossil in amber, as Cydnidae } \\
\text { incertae sedis }\end{array}$ \\
\hline \multicolumn{3}{|l|}{ Garsauriinae } \\
\hline Garsauriella haglundi (Bergroth) & Linnavuori, 1993 & N5 (habitus, head, different body parts) \\
\hline \multicolumn{3}{|l|}{ Cephalocteinae (Scaptocorini) } \\
\hline Atarsocoris brachiariae Becker & Medeiros \& Sales Jr., 2000 & N1 (descr.), N5 (descr.) \\
\hline Schiodtella secunda J.A. Lis & Lis, 1991 & N5 (descr., habitus) \\
\hline \multirow[t]{2}{*}{ Stibaropus henkei (Jakovlev) } & Halászfy, 1958 & N2 (descr.), N4 (descr.), N5 (habitus) \\
\hline & Putshkov, 1961 & N3-N5 (descr.) \\
\hline Stibaropus indonesicus J.A. Lis & Wilbrink, 1912 & $\begin{array}{l}\text { N1 (descr., habitus), N5 (descr., habitus), as } \\
\text { Stibaropus molginus (Schiødte) }\end{array}$ \\
\hline \multicolumn{3}{|l|}{ Sehirinae (Sehirini) } \\
\hline Adomerus biguttatus (Linnaeus) & Putshkov, 1961 & N1-N5 (descr.) \\
\hline \multirow[t]{2}{*}{ Canthophorus dubius (Scopoli) } & Putshkov, 1961 & N1-N5 (descr.) \\
\hline & Hertzel \& Scharmann, 1973 & N1-N5 (habitus) \\
\hline Canthophorus melanopterus (Herrich-Schaeffer) & Halászfy, 1958 & N5 (descr.) \\
\hline \multirow[t]{2}{*}{ Canthophorus niveimarginatus Scott } & Ishihara, 1946 & N5 (descr., habitus), as Sehirus niveimarginatus \\
\hline & Kobayashi, 1964 & N1-N5 (descr., habitus), as Sehirus niveimarginatus \\
\hline \multirow[t]{2}{*}{ Legnotus limbosus (Geoffroy) } & Halászfy, 1958 & $\mathrm{~N} 2$ (descr.) \\
\hline & Putshkov, 1961 & N1-N5 (descr.) \\
\hline \multirow[t]{2}{*}{ Legnotus picipes (Fallén) } & Halászfy, 1958 & N2 (descr., habitus) \\
\hline & Putshkov, 1961 & N1-N5 (descr.), N5 (habitus) \\
\hline \multirow[t]{2}{*}{ Ochetostethus opacus (Scholtz) } & Halászfy, 1958 & $\begin{array}{l}\text { N5 (descr.), as Ochethostethus nanus (Herrich- } \\
\text {-Schaeffer) }\end{array}$ \\
\hline & Putshkov, 1961 & $\begin{array}{l}\text { N1-N5 (descr.), as Ochethostethus nanus (Herrich- } \\
\text {-Schaeffer) }\end{array}$ \\
\hline Sehirus cinctus (Palisot de Beauvois) & McDonald, 1968 & N1-N5 (descr. habitus) \\
\hline Sehirus luctuosus Mulsant et Rey & Putshkov, 1961 & N1-N5 (descr.), N1 (head), N5 (head) \\
\hline \multirow[t]{4}{*}{ Tritomegas bicolor (Linnaeus) } & Southwood, 1949 & $\begin{array}{l}\text { N1 (descr., habitus), N2-N5 (descr.), as Sehirus } \\
\text { bicolor }\end{array}$ \\
\hline & Paul, 1953 & N5 (descr.), as Sehirus bicolor \\
\hline & Halászfy, 1958 & N5 (descr.) \\
\hline & Putshkov, 1961 & N1-N5 (descr.), as Canthophorus bicolor \\
\hline \multirow[t]{2}{*}{ Tritomegas sexmaculatus (Rambur) } & Halászfy, 1958 & $\begin{array}{l}\text { N4 (descr.), N5 (descr., habitus), as Canthophorus } \\
\text { sexmaculatus }\end{array}$ \\
\hline & Putshkov, 1961 & $\begin{array}{l}\text { N1-N5 (descr.), N1, N3, N5 (head), as } \\
\text { Canthophorus sexmaculatus }\end{array}$ \\
\hline \multicolumn{3}{|l|}{ Cydninae (Cydnini) } \\
\hline Chilocoris somalicus Mancini & Bertini, 1978 & N1 (habitus), N5 (habitus) \\
\hline Chilocoris umbricola Linnavuori & Linnavuori, 1993 & N5 (head, pronotum) \\
\hline \multirow[t]{3}{*}{ Cydnus aterrimus (Forster) } & Schorr, 1957 & N1-N5 (habitus), as Brachypelta aterrima \\
\hline & Halászfy, 1958 & N5 (descr., habitus) \\
\hline & Putshkov, 1961 & N1-N5 (descr.) \\
\hline \multicolumn{3}{|l|}{ Cydninae (Geotomini) } \\
\hline Adrisa birmana J.A. Lis & Lis, 1992 & N5 (descr., habitus) \\
\hline \multirow[t]{2}{*}{ Byrsinus fossor (Mulsant et Rey) } & Halászfy, 1958 & N5 (descr., habitus) \\
\hline & Putshkov, 1961 & N1-N5 (descr.) \\
\hline Byrsinus flavicornis (Fabricius) & Putshkov, 1961 & N1-N5 (descr.) \\
\hline Byrsinus pilosulus (Klug) & Linnavuori, 1993 & N5 (head, thorax), as Aethus pilosulus \\
\hline Cydnochoerus nigrosignatus (Buchanan White) & Larivière, 1995 & N5 (descr., habitus), as Choerocydnus nigrosignatus \\
\hline Fromundus hirtipes (Palisot de Beauvois) & Linnavuori, 1993 & N5 (head), as Geotomus hirtipes \\
\hline Fromundus pygmaeus (Dallas) & Kobayashi, 1964 & N1-N5 (descr., habitus), as Geotomus pygmaeus \\
\hline Geocnethus pallipennis (Dallas) & Linnavuori, 1993 & N5 (habitus) \\
\hline Geocnethus plagiatus (Signoret) & Linnavuori, 1993 & N5 (different body parts) \\
\hline Geotomus punctulatus (Costa) & Putshkov, 1961 & N1-N5 (descr.) \\
\hline \multirow[t]{2}{*}{ Macroscytus australis (Erichson) } & Hickman, 1978 & N1-N5 (descr., habitus), as Philapodemus australis \\
\hline & Larivière, 1995 & N5 (descr., habitus), as Philapodemus australis \\
\hline Macroscytus brumneus (Fabricius) & Moizuddin \& Ahmad, 1985 & $\begin{array}{l}\text { N1-N5 (descr., habitus), as Macroscytus subaeneus } \\
\text { (Dallas) }\end{array}$ \\
\hline \multirow[t]{3}{*}{ Microporus nigrita (Fabricius) } & Halászfy, 1958 & N2 (descr.), N5 (descr., habitus), as Aethus nigritus \\
\hline & Putshkova, 1959 & N1 (head), as Aethus nigritus \\
\hline & Putshkov, 1961 & $\begin{array}{l}\text { N1-N5 (descr.) N1 (head), N5 (head), as Aethus } \\
\text { nigritus }\end{array}$ \\
\hline
\end{tabular}


6. Chilocoris nepalensis J.A. Lis, 1994 [N2-N5, A, Nepal, DBUO];

7. Chilocoris tenebricola Jeannel, 1913 [N5, A, Senegal, $\mathrm{MNHN}]$;

Cydninae (Geotomini)

8. Adrisa punctulata (Dallas, 1851) [N3-N5, Australia, DBUO];

9. Adrisa rugosa (Dallas, 1851) [N4-N5, A, Australia, DBUO];

10. Adrisa similis Signoret, 1881 [N4-N5, A, Australia, DBUO];

11. Aethus lindbergi Wagner, 1957 [N5, A, Senegal, MNHN];

12. Aethoscytus multisetosus (Noualhier, 1898) [N5, A, Senegal, MNHN];

13. Byrsinus pseudosyriacus (Linnavuori, 1977) [N5, A, Senegal, MNHN];

14. Cydnochoerus nigrosignatus (Buchanan White, 1878) [N5, A, New Zealand, DBUO];

15. Endotylus brevicornis Horváth, 1919 [N5, A, Senegal, $\mathrm{MNHN}]$

16. Fromundus glaber (Signoret, 1858) [N1-N5, A, Senegal, $\mathrm{MNHN]}$

17. Fromundus parcimonius (Signoret, 1858) [N5, A, Senegal, MNHN];

18. Macroscytus australis (Erichson, 1842) [N5, A, Australia DBUO];

19. Macroscytus brunneus (Fabricius, 1803) [N1-N5, A, Senegal, MNHN];

20. Microporus laticeps (Signoret, 1882) [N5, A, India, DBUO];

21. Microporus lautipennis (Stål, 1858) [N5, A, Senegal, $\mathrm{MNHN}]$

22. Paraethus capicola (Westwood, 1837) [N1-N5, A, Senegal, MNHN];

23. Paraethus saprinoides (Gerstaecker, 1873) [N1-N5, A, Senegal, MNHN];

24. Scoparipes affinis J.A. Lis, 1990 [N5, A, Java, DBUO];

Sehirinae (Sehirini)

25. Canthophorus dubius (Scopoli, 1763) [N4-N5, A, France, Poland, MNHN, DBUO];

26. Canthophorus maculipes (Mulsant et Rey, 1852) [N1-N5, A, France, MNHN];

27. Lalervis tibialis (Stål, 1854) [N5, A, Kenya, DBUO];

Amnestinae

28. Amnestus raunoi J.A. Lis, 1998 [A, Iran, DBUO];

29. Amnestus uhleri Distant, 1880 [A, Brazil, DBUO];

30. Amnestus brunneus Signoret, 1883 [A, Brazil, DBUO];

31. Amnestus sp. [A, MNHN]

Methods. The specimens were treated with $\mathrm{KOH}$ and depigmented in $\mathrm{H}_{2} \mathrm{O}_{2}$, if necessary prior to study. The heads were mounted in lactophenol or glycerol, and observed and drawn using standard optical equipment.

The concept of the family is that of Froeschner (1960) and Lis (1994); for a discussion of the composition of the family see Lis (1994, p. 7-9).

\section{RESULTS}

\section{Types of cephalic setae in Cydnidae and their} terminology

All cephalic setae in the Cydnidae (Figs 28, 30, 32, 33, $34,35)$, even very robust setae, are structurally sensory

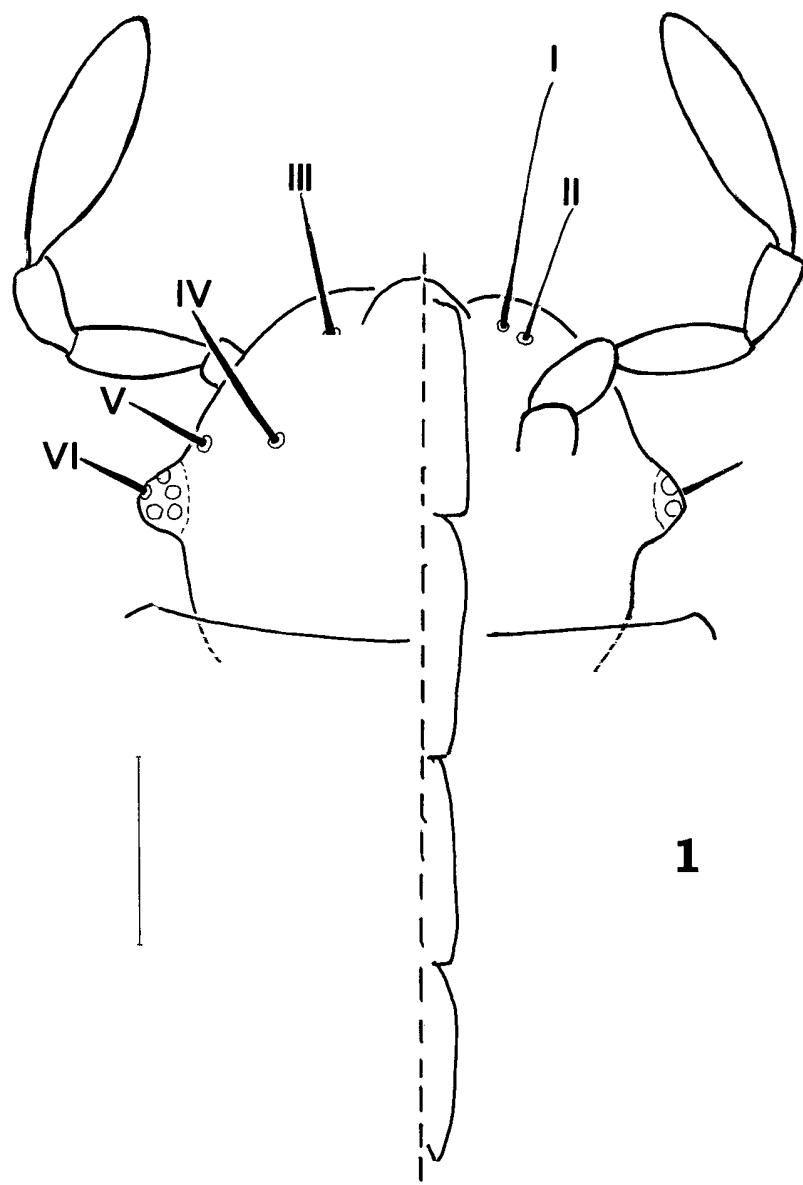

Fig. 1. Cephalic primary setae of the $1^{\text {st }}$ instar nymph of the subfamily Cydninae - dorsal view (left), ventral view (right). For explanation of the cephalic setae numbering - see the text. Scale: $0.1 \mathrm{~mm}$.

hairs or setae (sensilla trichodea or sensilla chaetica). They are thick-walled with a slightly narrower base inserted in a socket (Figs 29, 30, 31, 36).

Froeschner (1960), on the basis of the Signoret's (1881) fundamental paper, recognized two types of cephalic vestiture in Cydnidae - primary and secondary setae.

\section{Primary setae}

Cephalic primary setae (Fig. 1) appear to be a constant and basic character of nymphs and adults of almost all the species studied.

The general pattern of these setae is described for the subfamily Cydninae; for the other suprageneric groups of the family, modifications or exceptions to this pattern are given below.

Cydninae. The $\mathrm{N} 1$ of species of the subfamily Cydninae have six pairs of cephalic primary setae (Fig. 1); namely two setae (I-II) on the undersurface of an anterior part of each paraclypeus, three setae (III-IV-V) on the dorsal surface of each paraclypeus, and a single seta (VI) at the apical part of the eye. The same six pairs of setae (I-VI) are also present in N5 (Figs 2-20). Nevertheless, adults of a few species have fewer primary setae 

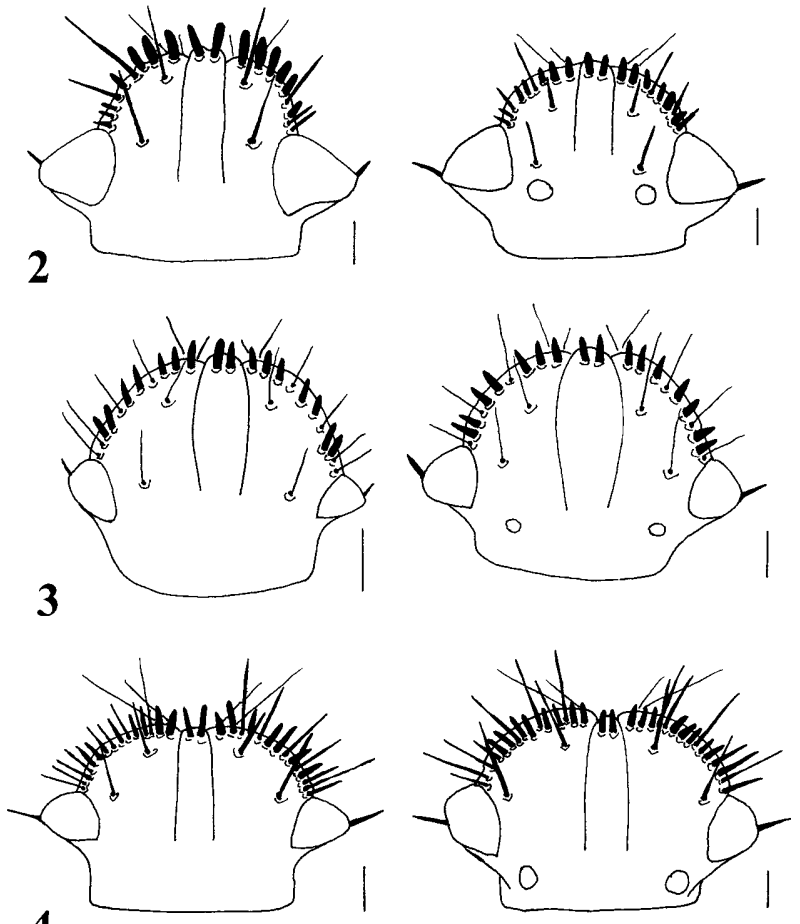

4
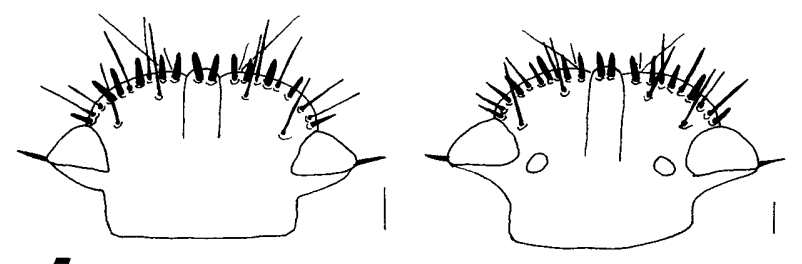

5
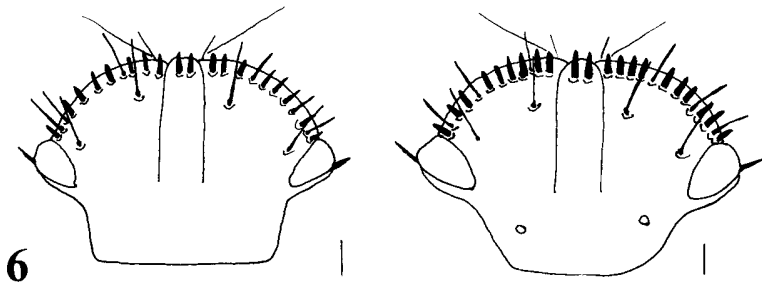

Figs 2-6. Cephalic chaetotaxy of the $5^{\text {th }}$ instar nymph (left) and adult (right) [Type 1 of Table 2]. 2 - Chilocoris tenebricola; 3 -Chilocoris nepalensis; 4 -Byrsinus pseudosyriacus; 5 - Microporus lautipennis; 6 - Microporus laticeps. Scale: 0.1 $\mathrm{mm}$.

(Figs 16-20) - the ocular apical seta (VI) is absent in adults of Cydnochoerus nigrosignatus, Scoparipes affinis, and Adrisa punctulata, and two pairs of primary setae (V - preocular, and VI - ocular) in adults of Adrisa rugosa and $A$. similis.

Cephalocteinae Scaptocorini. The ocular apical seta (VI) is absent in all nymphal (N1-N5) and adult stages (Figs 21-23).

Sehirinae Sehirini. Only a single pair of primary cephalic setae is present in nymphal (N4-N5) and adult stages (Figs 24-25), namely the ocular apical seta (VI); this seta is sometimes very short and hardly visible, but is always present. All other primary setae are absent in the nymphal (N4-N5) and adult stages (Figs 24-25).
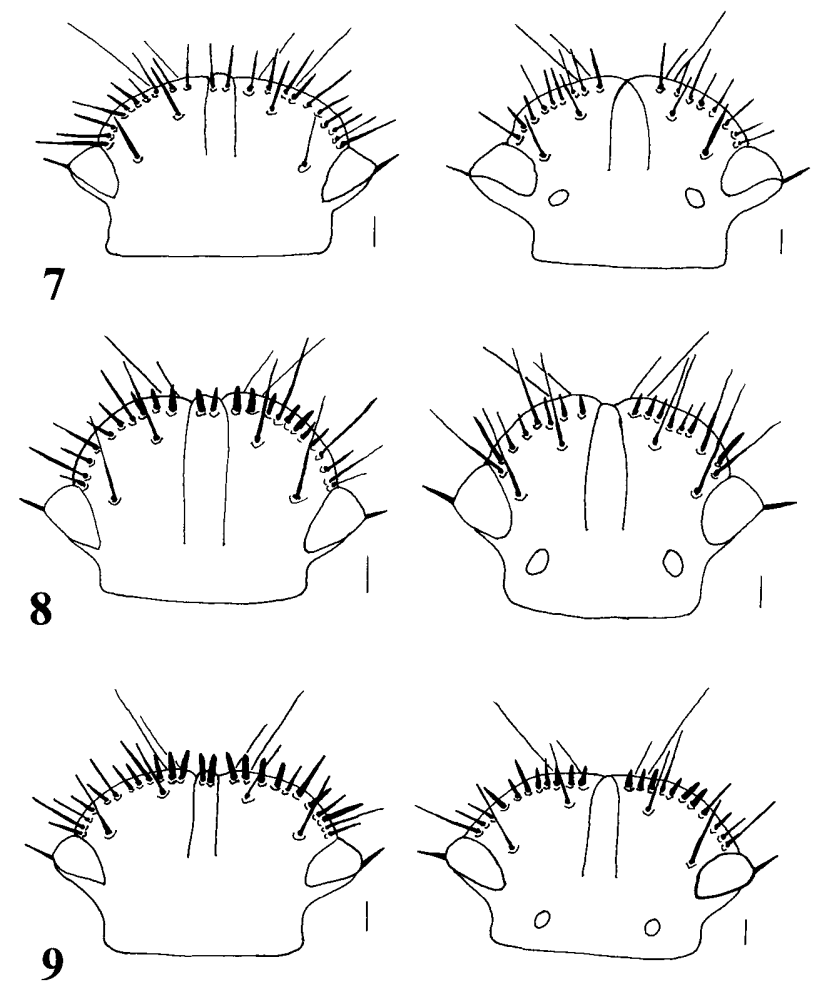

Figs 7-9. Cephalic chaetotaxy of the $5^{\text {th }}$ instar nymph (left) and adult (right) [Type 2 of Table 2]. 7 -Aethoscytus multisetosus; 8 - Aethus lindbergi; 9 - Paraethus capicola. Scale: 0.1 $\mathrm{mm}$.

Garsauriinae. The species of this subfamily have only four pairs of primary setae (III-IV-V-VI) in both nymphal (N5) and adult stages; setae I and II are absent (Fig. 26). The pairs III-IV-V are normally developed and obvious, although setae are usually torn out and thus may appear to be absent (therefore Froeschner, 1960, and Dolling, 1981 recorded Garsauriinae as lacking cephalic setae). Setae III-VI in N5 of Garsauria laosana are present in the same position as in N5 of all Cydninae (Fig. 26), but due to the allometric growth of the adult head the first paraclypeal pair of setae (III) is shifted anteriorly and thus directed forward (the same is true of adult G. aradoides Walker). The ocular apical seta (VI) in both N5 and adults of Garsauriinae is short, stout and sharp, and accompanied by a few additional stout sharp setae on the posterior eye margin.

Amnestinae. The number and arrangement of primary setae in the subfamily Amnestinae is very uncertain because only adults were studied. All six pairs (I-VI) of primary setae occur on the head (Fig. 27), although usually the apical eye seta (VI) is torn out and appears to be absent. The first pair (I) of primary setae is shifted forward to the head margin or even onto its dorsal surface. Since sometimes there is an additional pair of paraclypeal setae on the dorsal margin of the head, adult Amnestinae appear to possess four to five paraclypeal primary setae (Froeschner, 1960). Nevertheless, the drawing of the $5^{\text {th }}$ instar of a fossil Amnestus sp. (Thomas, 1988) indicates it has only three pairs of primary setae (III-IV-V), and thus 
TABLE 2. Main differences in the patterns of cephalic setae in Cydnidae [presence $(+)$ and absence $(-)$ of primary and secondary setae], and significant differences (loss of setae) between $5^{\text {th }}$ instar nymph (N5) and adult (A) stages. ++ in $\mathrm{N} 5$ and ++ in $\mathrm{A}=$ no change in number of secondary setae in adult compared to $5^{\text {th }}$ instar; ++ in $\mathrm{N} 5$ and +- in $\mathrm{A}=$ decrease in number of secondary setae in adults compared to $5^{\text {th }}$ instar.

\begin{tabular}{llllllllllll}
\hline & \multicolumn{1}{c}{ Primary setae } & \multicolumn{7}{c}{ Secondary setae } \\
\cline { 2 - 9 } & \multicolumn{3}{c}{ I } & II & III & IV & V & VI & Paraclyp. Clypeus \\
\hline Type 1 & N5 & + & + & + & + & + & + & ++ & + & Cydninae Geotomini \& Cydnini part (Figs 2-6), \\
& A & + & + & + & + & + & + & ++ & + & Amnestinae (Fig. 27) \\
Type 2 & N5 & + & + & + & + & + & + & ++ & + & Cydninae Geotomini (part) \\
& A & + & + & + & + & + & + & ++ & - & (Figs 7-9) \\
Type 3 & N5 & + & + & + & + & + & + & ++ & + & Cydninae Cydnini (part) \\
& & + & + & + & + & + & + & +- & + & (Figs 14, 15) \\
Type 4 & N5 & + & + & + & + & + & + & ++ & + & Cydninae Geotomini (part) \\
& & + & + & + & + & + & + & +- & - & (Figs 10-13) \\
Type 5 & N5 & + & + & + & + & + & + & ++ & + & Cydninae Geotomini (part) \\
& A & + & + & + & + & + & - & ++ & + & (Figs 16-18) \\
Type 6 & N5 & + & + & + & + & + & + & - & + & Cydninae Geotomini (part) \\
& A & + & + & + & + & - & - & - & - & (Figs 19, 20) \\
Type 7 & N5 & + & + & + & + & + & - & ++ & + & Cephalocteinae Scaptocorini \\
& A & + & + & + & + & + & - & ++ & + & (Figs 21-23) \\
Type 8 & N5 & - & - & + & + & + & + & - & - & Garsauriinae \\
& A & - & - & + & + & + & + & - & - & (Fig. 26) \\
Type 9 & N5 & - & - & - & - & - & + & - & - & Sehirinae Sehirini \\
& A & - & - & - & - & - & + & - & - & (Figs 24, 25) \\
\hline
\end{tabular}

the fourth paraclypeal seta (regarded by Froeschner, 1960 , as a primary seta) is an additional seta having nothing to do with the three primary setae.

\section{Secondary setae}

Cephalic secondary vestiture is only present in Amnestinae (Fig. 27), Cephalocteinae (Figs 21-23), and Cydninae (Figs 2-20); it is present in the first instar nymphs, at least in some species (Cydninae, Cephalocteinae). The secondary setae are absent in nymphs and adults of Garsauriinae (Fig. 26) and Sehirini (Figs 24-25).

These setae display a great diversity and are far more variable (in number, pattern and types) than the primary setae; moreover, they show a generic and intraspecific variation.

It was proposed previously (Lis, 1994), on the basis of their morphology, that the cephalic secondary setae can be classified into three groups as follows (already recognized by Signoret, 1881).

1. Hair-like setae ("cils" of Signoret; "hairs" of Froeschner; "bristles" of Linnavuori) - long, hair-like, slender along their entire length, usually similar to the primary setae (Fig. 35);

2. Peg-like setae ("spinules" of Signoret; "pegs" of Froeschner; "spines" of Linnavuori) - shorter and stouter than preceding, with the apex more or less sharp, basally clearly stouter than apically (Figs 28, 29, 34);

3. True-pegs ("lamelles" of Signoret) - the most robust and the shortest, usually blunt apically, sometimes slightly sharpened (Figs 32, 33).
There are, however, intermediate forms between types 1, 2 and 3, and it is sometimes difficult to ascribe a given seta to one of the three types. For instance, in genera Chilocoris Mayr and Amnestus Dallas it is difficult to decide whether the cephalic setae are of type (2) or (3) [setae on and close to the clypeus are very often "true-pegs", whereas those placed more posteriorly are "peg-like setae"]. Therefore, for practical reasons two names - hairlike setae [type (1)] and peg-like setae [types (2) and (3)] are suggested, as proposed by Froeschner (1960) and Linnavuori (1993).

In the most species (Figs 2-6, 8-9, 17, 21) the head of nymphs and adults bears a row of both types of secondary setae, often alternately, namely hair-like and peg-like setae (Scaptocoris australis, Chilocoris tenebricola, Ch. nepalensis, Microporus laticeps, M. lautipennis, Byrsinus pseudosyriacus, Scoparipes affinis, Aethus lindbergi, Paraethus capicola), although in some species only one type of cephalic secondary setae is present, either hairlike setae (Adrisa punctulata, A. rugosa, A. similis, Macroscytus australis, M. brunneus, Aethoscytus multisetosus, Cydnochoerus nigrosignatus - Figs 7, 10, 15-16, 18-20), or peg-like setae (Pseudostibaropus testaceus, Stibaropus pseudominor - Figs 22-23).

\section{Intraspecific variation}

In a given species, the pattern of secondary setae is constant. There is some variation in the number of secondary setae between individuals. For instance, the number of paraclypeal setae on each side of the head may vary from 11 to 13 in Paraethus capicola, and from 8 to 11 in Stibaropus pseudominor; some authors have already noted this, e. g., Linnavuori, 1993; Lis, 1994, 2000. 


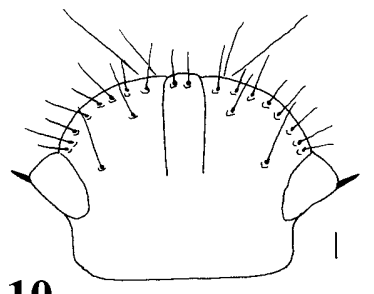

10
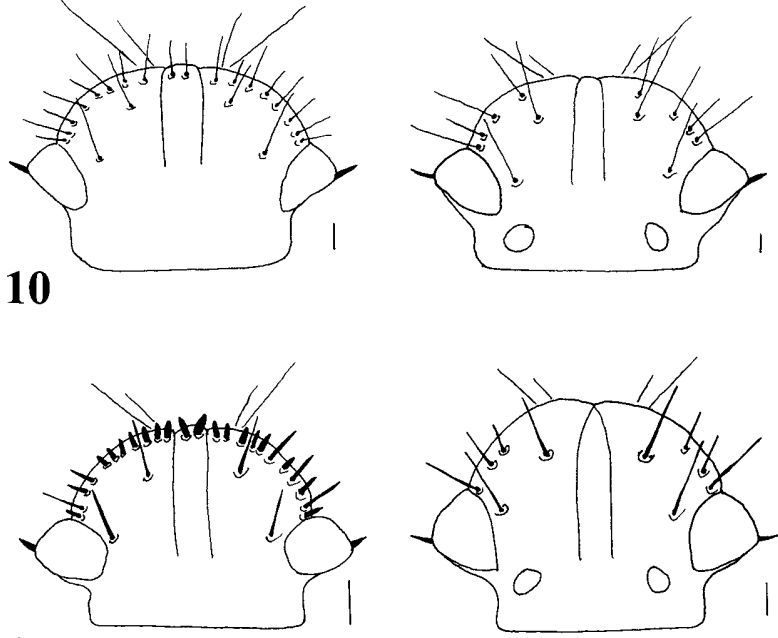

11
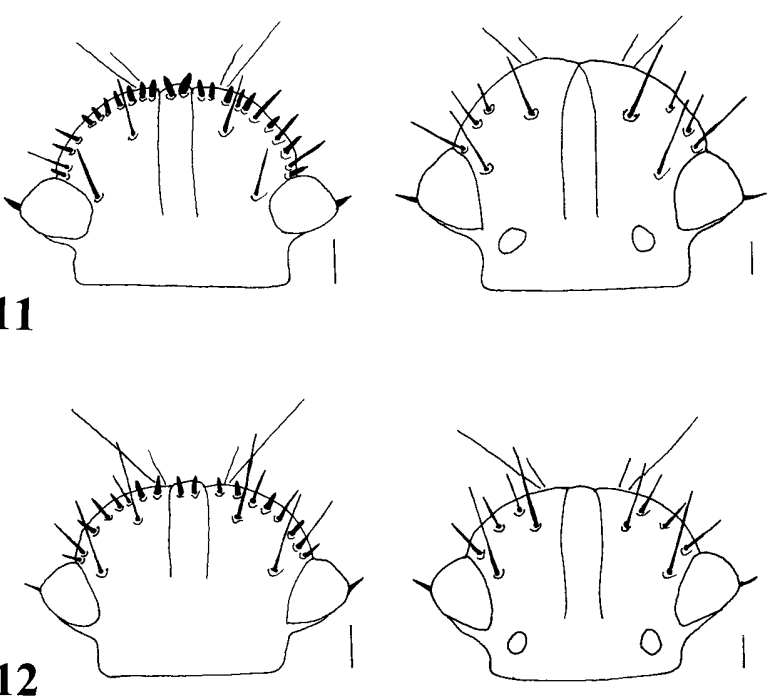

12
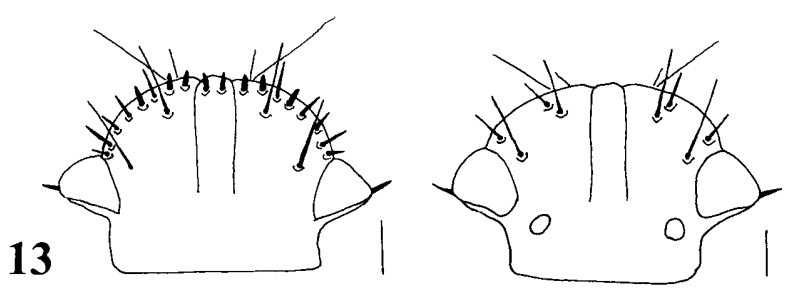

Figs 10-13. Cephalic chaetotaxy of the $5^{\text {th }}$ instar nymph (left) and adult (right) [Type 4 of Table 2]. 10 - Macroscytus brunneus; 11 - Endotylus brevicornis; 12 - Fromundus parcimonius; 13 - Fromundus glaber. Scale: $0.1 \mathrm{~mm}$.

\section{Changes during ontogenesis}

In all species whose nymphs were examined, the pattern of cephalic setae remains the same throughout nymphal life; the setae present in the first instar are present in the fifth instar nymph.

On the other hand, in some species, there are changes in the type and pattern of the setae in the adult stage. In a few species (Cydnus aterrimus, Endotylus brevicornis, Fromundus parcimonius, Fromundus glaber) the type of secondary setae appears to change during ontogenesis (peg-like setae in the $5^{\text {th }}$ instar, hair-like setae in the adult - Figs 11-14). But above all, there is a loss of setae in the adult stage. This is considered below by comparing the fifth instar nymphs and adult stages.

\section{Comparison of nymphal $\left(5^{\text {th }}\right.$ instar) and adult cephalic chaetotaxy}

Depending on the species, there are some or no differences between nymphal and adult chaetotoxy. The differ-
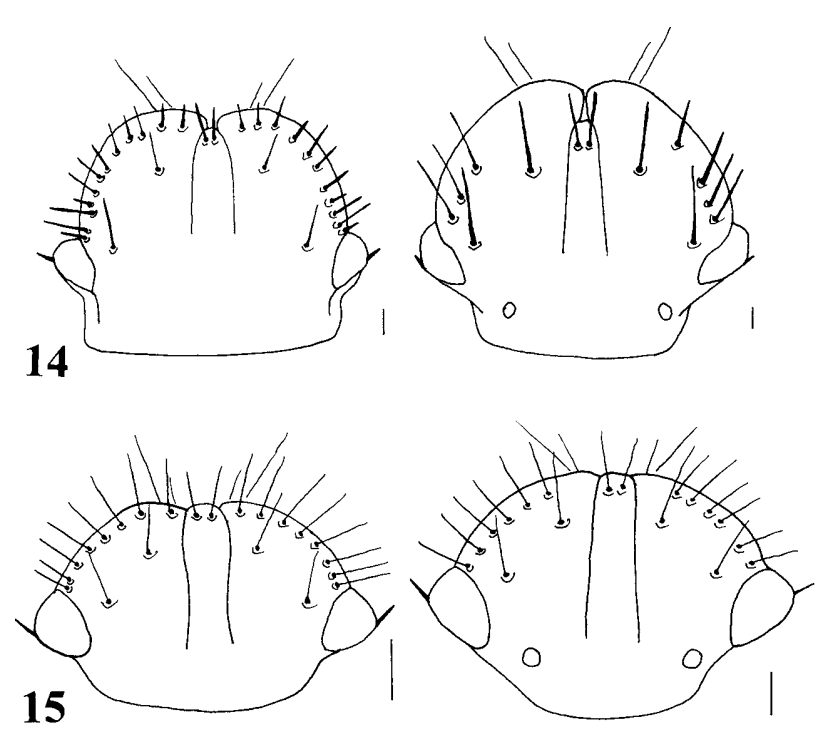

Figs 14-15: Cephalic chaetotaxy of the $5^{\text {th }}$ instar nymph (left) and adult (right) [Type 3 of Table 2]. 14 - Cydnus aterrimus; 15 - Macroscytus australis. Scale: $0.1 \mathrm{~mm}$.

ences are mainly in the loss or regression of setae and can be divided into 9 categories (Table 2).

\section{Adult and nymphal chaetotaxy identical}

The cephalic chaetotaxies of nymphal and adult stages (Figs 2-6, 21-25) are exactly the same in terms of the type and pattern of setae (Table 2: types 1, 7-9). This phenomenon occurs in three subfamilies, Cephalocteinae Scaptocorini (Scaptocoris australis, Stibaropus pseudominor, Pseudostibaropus testaceus), Cydninae Cydnini in part (Chilocoris tenebricola, Ch. nepalensis), Cydninae Geotomini in part (Microporus laticeps, M. lautipennis, Byrsinus pseudosyriacus, Macroscytus australis), and Sehirinae Sehirini (Lalervis tibialis, Canthophorus dubius).

\section{Adult and nymphal chaetotaxy differ}

The cephalic chaetotaxy of adults differs from that of the nymphal stages; several kinds of modifications can be recognized within the Cydnidae regarding the loss of setae (primary or secondary) (Table 2); morphological modifications also occur.

\section{Loss of secondary setae}

Type 2: Loss of the two clypeal setae (Aethoscytus multisetosus, Aethus lindbergi, Paraethus capicola) (Figs 7-9);

Type 3: Decrease in number of paraclypeal setae with retention of the two clypeal setae (Cydnus aterrimus, Macroscytus australis) (Figs 14-15);

Type 4: Decrease in number of paraclypeal setae and loss of the two clypeal setae (Macroscytus brunneus, Endotylus brevicornis, Fromundus glaber, F. parcimonius) (Figs 10-13). 

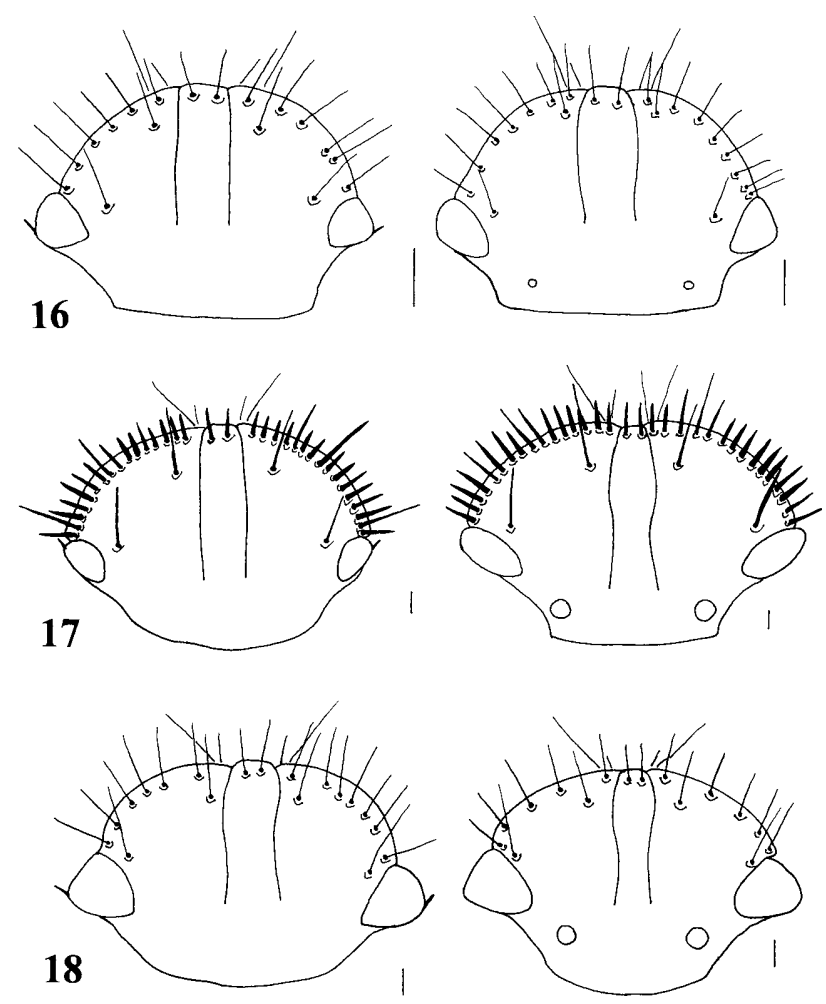

Figs 16-18. Cephalic chaetotaxy of the $5^{\text {th }}$ instar nymph (left)

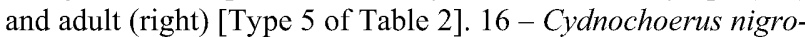
signatus; 17 - Scoparipes affinis; 18 - Adrisa punctulata. Scale: $0.1 \mathrm{~mm}$

\section{Loss of primary setae}

Type 5: Loss of ocular setae (VI) (Cydnochoerus nigrosignatus, Scoparipes affinis, Adrisa punctulata) (Figs $16-18)$;

Type 6: Loss of primary paraclypeal setae V-VI plus loss of the two clypeal secondary setae (Adrisa rugosa, $A$. similis) (Figs 19-20).

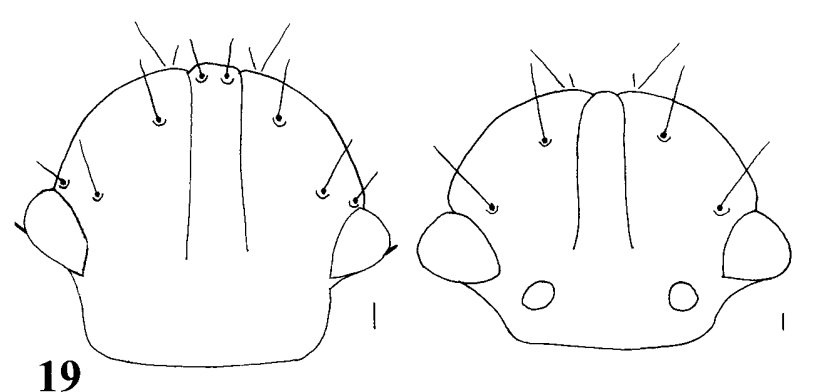

19

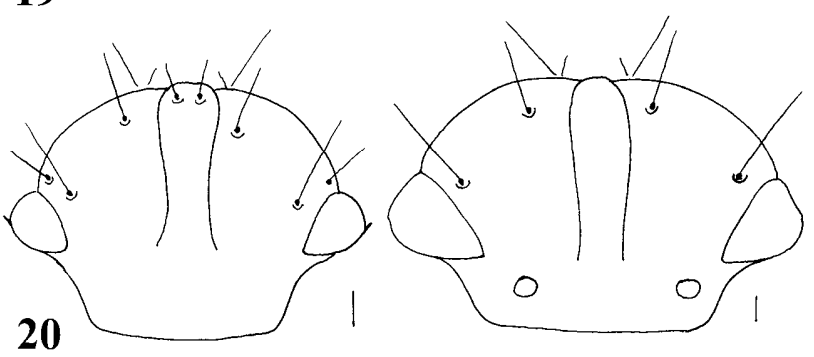

Figs 19-20. Cephalic chaetotaxy of the $5^{\text {th }}$ instar nymph (left) and adult (right) [Type 6 of Table 2]. 19 - Adrisa rugosa; $20-$ Adrisa similis. Scale: $0.1 \mathrm{~mm}$.
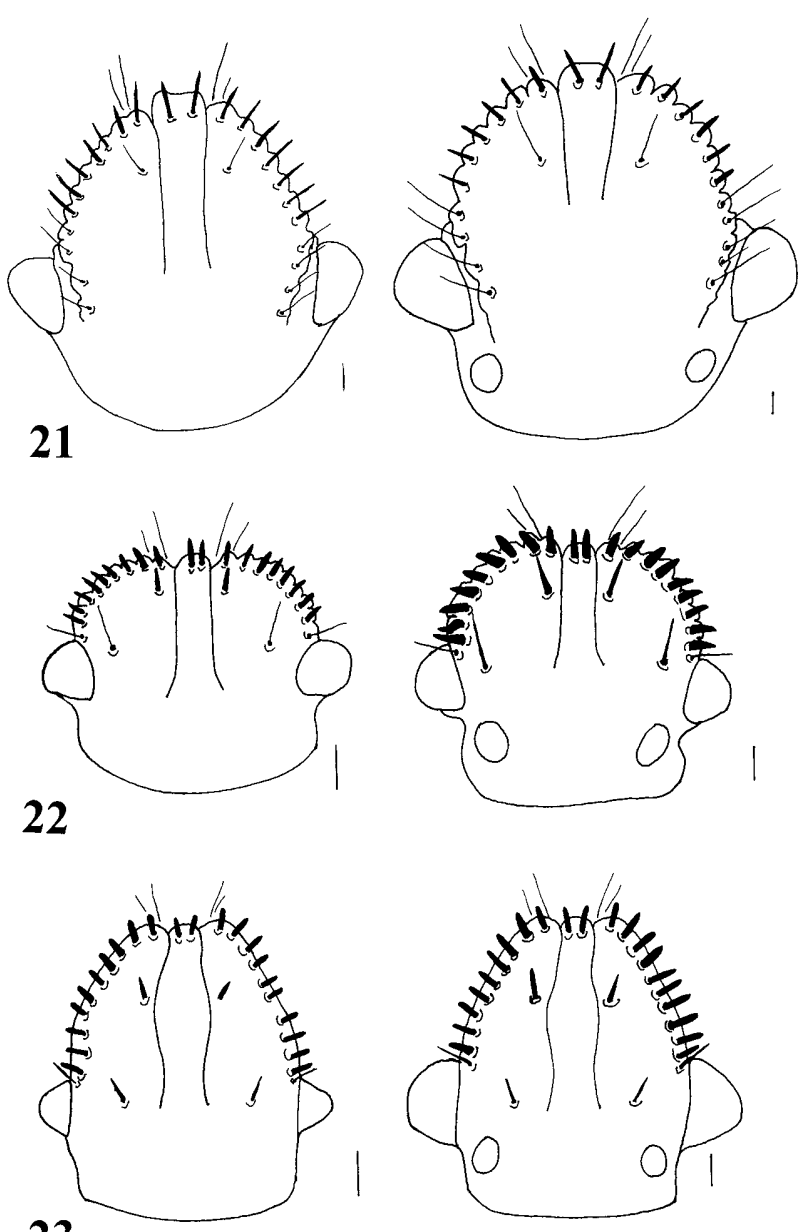

23

Figs 21-23. Cephalic chaetotaxy of the $5^{\text {th }}$ instar nymph (left) and adult (right) [Type 7 of Table 2]. 21 - Scaptocoris australis; 22 - Stibaropus pseudominor; 23 - Pseudostibaropus testaceus. Scale: $0.1 \mathrm{~mm}$.

\section{Other modifications observed}

The submarginal row of secondary peg-like setae on paraclypei transformed into a few submarginal hair-like setae in the adult (Endotylus brevicornis, Fromundus glaber, F. parcimonius) (Figs 11-13);

Primary setae III-IV-V shifted forward (Garsauria laosana) (Fig. 26);

Primary seta I shifted forward, and sometimes additional hair-like setae are present on paraclypei close to the clypeus (Amnestus) (Fig. 27).

\section{DISCUSSION}

The present study of the chaetotaxy of nymphal and adult stages of Cydnidae, in particular the changes that occur during ontogeny, provide information in three different fields: adaptation, taxonomy and phylogeny.

\section{Cephalic setae an adaptive trait for a specific mode of life}

The presence of cephalic primary setae, as well as two easily recognized types of secondary setae (hair-like and peg-like) in both nymphal and adult stages of Cydnidae, is unique to the Pentatomoidea; setae of similar stoutness 


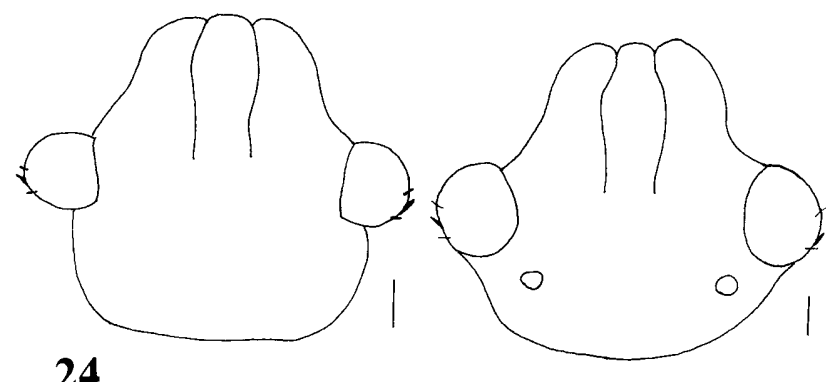

24
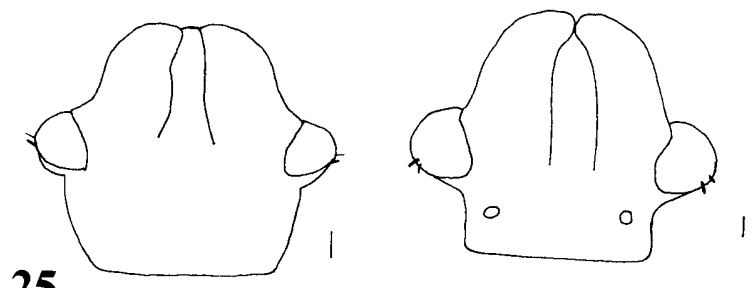

25
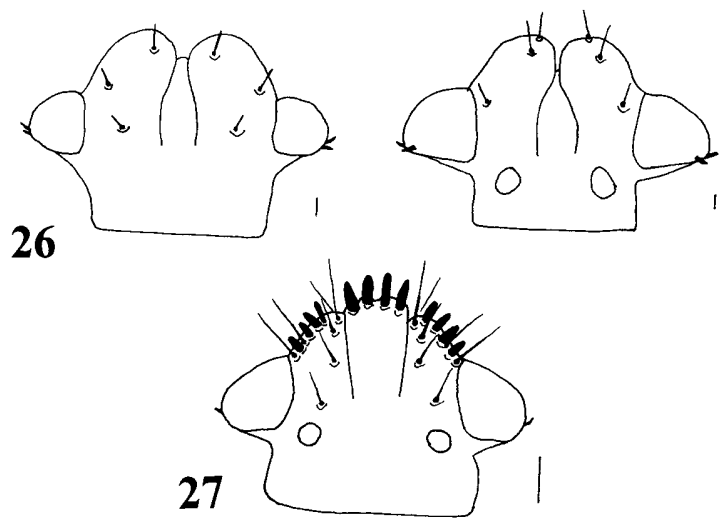

Figs 24-27. 24-26: Cephalic chaetotaxy of the $5^{\text {th }}$ instar nymph (left) and adult (right). [Type 9 of Table 2]. 24 - Lalervis tibialis; 25 - Canthophorus dubius; 26 - Garsauria laosana [Type 8 of Table 2]. Scale: $0.1 \mathrm{~mm} .27$ - Amnestus sp., cephalic chaetotaxy of the adult [Type 7 of Table 2]. Scale: 0.1 $\mathrm{mm}$.

and position are unknown in other shieldbugs (Dolling, 1981; Linnavuori, 1993; Lis, unpublished data). It is most probably connected with their mode of life - they live deep in the soil, under stones or in litter. Several facts or arguments support this hypothesis.

1. The development of tactile setae (mechanoreceptors) like primary setae is regarded by many authors (e. g., China, 1955; Cobben, 1978) as characteristic of all ground-living bugs; furthermore, among Pentatomomorpha this type of cephalic setae is known only in the Rhyparochromidae, which are also ground-dwelling bugs (Cobben, 1978; Schuh, 1975; Dolling, 1981; Henry, 1997).

2. The rounded and usually flattened head of Cydnidae with its circular crown of setae (hair-like or peg-like) (Figs 28, 32, 34) suggests a bulldozer or a digger, well adapted for pushing and digging. Similar crowns of strong setae are found in the ground-dwelling nymphs of pentatomid species of the tribe Sciocorini, Menaccarus arenicola (Scholtz) (Putshkov, 1961; Lis, per- sonal observation), as well as in the fossorial nymphs of Ochteridae [see in particular Dufour (1833), Bobb (1951) and Boulard \& Coffin (1991)], a family belonging to the Nepomorpha. The crown of setae developed independently in the Ochteridae, which have the same mode of life, and cryptic behaviour. Moreover, nymphs in both families (Ochteridae and Cydnidae), construct cavities in which they rest or moult (Boulard \& Coffin, 1991; Pluot-Sigwalt, unpubl.). Unlike Cydnidae and Menaccarus arenicola, adults of Ochteridae do not burrow and lack the crown of setae in the adult stage.

3. Within the family, an absence of almost all cephalic setae (primary and secondary) is characteristic of the non-burrowing representatives of the Sehirinae Sehirini (all species live above ground, on plants). However, the nymphal and adult stages of species of Garsauriinae have three pairs of cephalic primary setae in spite of the fact that they are not fossorial, but live under the bark of trees.

4. Unpublished observations on the biology and behaviour of several cydnid species seem to indicate a correlation between the robustness of cephalic setae and the incidence of burrowing. All species with peg-like setae (Figs 32, 33, 34) probably burrow deeply (e.g., Chilocoris, Byrsinus, Stibaropus, Microporus), whereas those with hair-like setae inhabit the litter or live under stones (for instance Macroscytus brunneus - Fig. 35).

5. A loss of setae in the adult stage may indicate a change in mode of life. Adults of many species are commonly collected on the ground or in a flight; they spend less time under ground than the nymphs. This was observed (unpubl. data) in Macroscytus brunneus, and probably in Endotylus brevicornis, Fromundus parcimonius and $F$. glaber. In the three latter species, the adults only have hair-like setae. Primary setae seem to be less obviously connected with fossorial habits than secondary setae, but setae I-II are only present in the soildwelling Scaptocorini, Cydninae, and Amnestinae; they are absent in both the nymphs and adults of the aboveground dwelling Sehirini and mycetophagous Garsauriinae. Moreover, setae I-II are absent in other representatives of Pentatomoidea (Lis, unpublished data).

\section{Cephalic chaetotaxy as a taxonomic character}

This study has confirmed that the head vestiture can have a taxonomic value. Congeners share the same type of cephalic vestiture, and undergo the same changes during ontogeny. However, there are exceptions, e. g., Macroscytus brunneus and $M$. australis, or Adrisa punctulata, $A$. similis, and $A$. rugosa, suggesting, most probably, the existence of species-groups within the genus. Moreover, as has already been noticed (Lis, 1994, 2000), the head vestiture differs between species and provides useful characters for their seperation. On the other hand, the taxonomic significance of the different types of secondary setae for defining the genera, should be reexamined, because of the changes in vestiture that occur during ontogeny. It is clear that grouping species within 

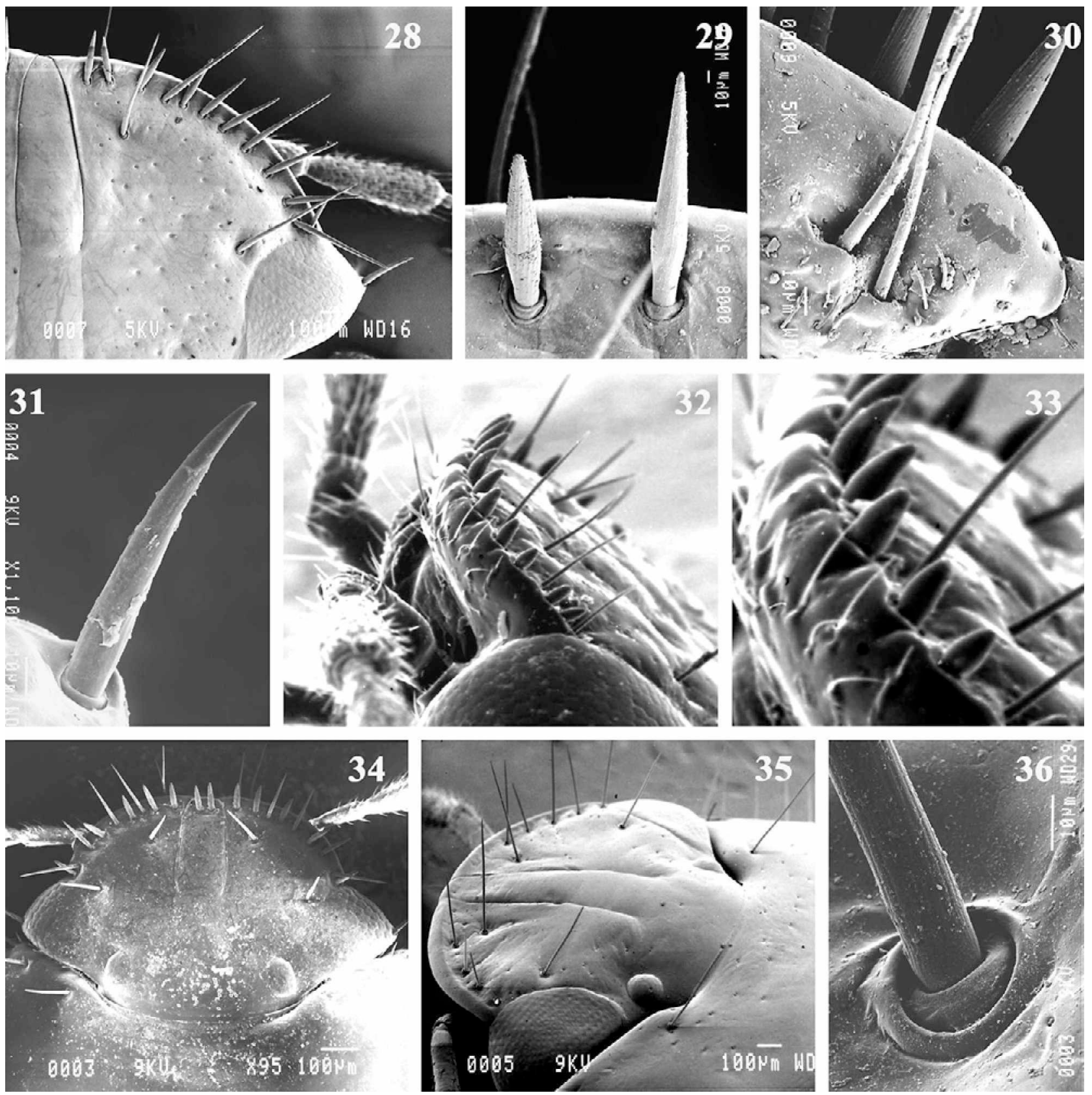

Figs 28-36. Cephalic setae of adults of Cydnidae. 28 - Endotylus brevicornis, right half of the head showing primary setae III, IV, $\mathrm{V}$, VI, and a row of submarginal secondary setae; 29 - Idem, two submarginal secondary setae in detail; 30 - Idem, ventral face of the head, with primary setae I and II; 31 - Idem, primary setae VI (ocular setae); 32 - Chilocoris somalicus, head with crown of strong setae (pegs and few hair-like setae); 33 - Idem, submarginal setae in detail; 34 - Microporus lautipennis, head with peg-like and hair-like setae; 35 - Macroscytus brunneus, head bearing hair-like setae only; 36 - Idem, the base of a seta in detail. (Copyright: "Service commun de microscopie électronique des Laboratoires des Sciences de la Vie, Muséum national d'Histoire naturelle, Paris").

certain genera solely on the basis of the cephalic vestiture is inappropriate, and must be supported by characters other than those associated with a specific mode of life.

\section{Cephalic chaetotaxy as a phylogenetic criterion}

As one might expect, the primary and secondary setae to be used in phylogenetic analyse; since each type of seta seems to have a different phylogenetic significance, they are discussed separately below.
Primary setae. The primary setae of the Cydnidae can be regarded as homologous to the cephalic setae of the nymphs and adults of many heteropteran groups (Leptopodomorpha; Gerromorpha; Ceratocombidae in Dipsocoromorpha; Plokiophilidae, Microphysidae, Anthocoridae, Nabidae, and Pachynomidae in Cimicomorpha; and Rhyparochromidae in Pentatomomorpha) and were considered by Cobben (1978), Schuh (1975), Dolling (1981), and Henry (1997) as trichobothria-like setae or true trichobothria. Moreover, the three pairs of trichobothria pre- 
sent were regarded by China (1955), Cobben (1978) and Dolling (1981) as attributes possessed by the heteropteran ancestor, which (according to these authors) was a ground-living, hygrophilous bug. Thus, the occurrence of these three pairs of cephalic primary trichobothria-like setae (III-IV-V) in Cydnidae appears to be plesiomorphic, and a decrease in the number of these setae can be regarded as an apomorphy. The loss of the preocular pair of setae (V) occurs in some Geotomini (Adrisa rugosa and A. similis), and of all three pairs of trichobothria-like setae in all Sehirini.

The displacement of the three pairs of trichobothria-like setae (III-IV-V) in adults of Garscaria laosana and $G$. aradoides, along with the forward displacement of the first pair (III), can be considered a synapomorphy.

The absence of the apical ocular seta (VI) in nymphal and adult stages of Scaptocorini, as well as in adults of some Geotomini (Cydnochoerus nigrosignatus, Scoparipes affinis, all species of Adrisa), is also an apomorphic state. Since some Lygaeoidea (e. g., Rhyparochromidae) and many more primitive groups of Heteroptera possess two ocular setae (instead of one) in the early instars, the gradual disappearance of these setae in the Pentatomomorpha may indicate an anagenetic trend (see Cobben, 1978).

The primary setae I-II (on the undersurface of an anterior part of each paraclypeus) were found only in Scaptocorini, Cydninae and Amnestinae; they are absent in both nymphs and adults of Sehirini and Garsauriinae, as well as in other families of Pentatomoidea (Lis, unpublished data). Their presence can be regarded as a synapomorphy, and their absence in Sehirini and Garsauriinae should be most probably treated as a reversal homoplasious state. The displacement of the seta I and its movement up onto the dorsal surface of the paraclypei in Amnestus (Amnestinae) is an autapomorphy of the genus and of the subfamily as well.

Secondary setae. Based on the changes that occur during ontogeny we assume that the presence of peg-like setae in both nymphal and adult stages is the most archaic state in the Cydnidae. The following evolutionary changes can be regarded as apomorphies: (1) total reduction of the secondary setae in nymphs and adults - Garsauriinae and Sehirinae; (2) presence of peg-like setae in nymphs but absence in adults - Endotylus brevicornis, Fromundus glaber, F. parcimonius; (3) loss of the clypeal pair of secondary setae - Adrisa rugosa, A. similis, Endotylus brevicornis, Fromundus glaber, F. parcimonius, Macroscytus brunneus, Aethoscytus multisetosus, Aethus lindbergi, Paraethus capicola); (4) fewer secondary setae in adults than in nymphs.

We conclude that the cephalic chaetotaxy of the Cydnidae-archetype included all the primary setae (I-VI), as well as a row of secondary peg-like setae along the entire lateral margins of the head (including clypeus) in both, nymphal and adult stages. Moreover, the three general anagenetic trends in cephalic chaetotaxy in the family Cydnidae can be hypothesized thus: (1) reduction in the number of primary setae, (2) reduction in the number of secondary setae leading in many cases to their entire loss, and (3) loss of peg-like setae during ontogeny.

ACKNOWLEDGEMENTS. We would like to express our gratitude to Mick Webb (the Natural History Museum, London, UK) for a language verification of the text, and to Delhi Guillaumin and Claude Pierre (Muséum National d'Histoire Naturelle, Paris, France) for their help and assistance in making the plate with the SEM photographs.

\section{REFERENCES}

BerTin H. 1978: Observations sur Certains Hémiptères Cydnidae se Nourrissant de Graines de Figues. Museum National d'Histoire Naturelle, Laboratoire d'Entomologie générale et appliquée, Rapport de stage (Diplôme d'études approfondies), Université de Paris VI, Paris, 55 pp.

Boвв M.L. 1951: Life history of Ochterus banksi Barber (Hemiptera: Ochteridae). Bull. Brookl. Entomol. Soc. 46: 92-100.

Boulard M. \& Coffin J. 1991: Sur la biologie juvénile d'Ochterus marginatus (Latreille, 1804). Camouflage et construction (Hemiptera: Ochteridae). Travaux Lab. Biol. Evol. Insectes, EPHE 4: 57-68.

ChINA W.E. 1955: The evolution of water bugs. Nat. Inst. Sci. India 7: 91-103.

Cobben R.H. 1978: Evolutionary trends in Heteroptera. Part II. Mouthpart-structures and feeding strategies. Meded. Landbouwhogeschool Wageningen 78: 1-407.

DolurNG W.R. 1981: A rationalized classification of the burrower bugs (Cydnidae). Syst. Entomol. 6: 61-76.

Durour L. 1833: Recherches anatomiques et physiologiques sur les Hémiptères accompagnées de considérations relatives à l'histoire naturelle et à la classification de ces insectes. Mém. Savants Etrang. Acad. Sci. Paris 4: 123-432.

Froeschner R.C. 1960: Cydnidae of the Western Hemisphere. Proc. U.S. Natn. Mus. 111: 337-680.

HALÁszFY E. 1958: Bemerkungen über einige Stadien der Larven von Pentatomoidea in der Zoologischen Abteilung des Ungarischen National-Museums. Acta Entomol. Mus. Natn. Pragae 32: 545-566.

HENRY T.J. 1997: Phylogenetic analysis of family groups within the infraorder Pentatomomorpha (Hemiptera: Heteroptera), with emphasis on the Lygaeoidea. Ann. Entomol. Soc. Am. 90: 275-301.

Hertzel G. \& Scharmann K.H. 1973: Beitrag zur Kenntnis der Biologie und Verbreitung von Canthophorus dubius (Scopoli, 1765) (Het.: Cydnidae). Entomol. Ber. (Berlin) 1973: 33-39.

Hickman V.V. 1978: The biology of Philapodemus australis (Erichson) (Hemiptera: Cydnidae). Gen. Appl. Entomol. 10: $45-49$.

IsHIHARA T. 1946: The fifth instar larvae of Sehirus niveimarginatus (Scott). Ins. World 50: 6-7 [in Japanese].

KobaYashi T. 1964: Developmental stages of Geotomus pygmaeus (Dallas) and Sehirus niveimarginatus (Scott) (Cydnidae). Kontyû 32: 21-27.

LARrvière M.-C. 1995: Cydnidae, Acanthosomatidae, and Pentatomidae (Insecta: Heteroptera): systematics, geographical distribution, and bioecology. Fauna of New Zealand 35: 1-109.

Linnavuori R.E. 1993: Cydnidae of West, Central and NorthEast Africa (Heteroptera). Acta Zool. Fenn. 192: 1-148.

LIS J.A. 1991: Schiodtella secunda n. sp., a new species of burrowing bugs from Palaearctic China (Heteroptera: Cydnidae: Scaptocorinae). Genus (Wroctaw) 2: 27-31.

Lis J.A. 1992: Studies on Oriental Cydnidae. IX. On the genus Adrisa Amyot and Serville, 1843 (Heteroptera: Pentatomoidea). Genus (Wroctaw) 3: 13-27. 
Lis J.A. 1994: A Revision of Oriental Burrower Bugs (Heteroptera: Cydnidae). Upper Silesian Museum, Department of Natural History, Bytom, $349 \mathrm{pp}$.

Lis J.A. 2000: A revision of the burrower-bug genus Macroscytus Fieber, 1860 (Hemiptera: Heteroptera: Cydnidae). Genus (Wroclaw) 11: 359-509.

MCDONald F.J.D. 1968: Some observations on Sehirus cinctus (Palisot de Beauvois) (Heteroptera: Cydnidae). Canad. J. Zool. 46: 855-858.

Mederros M.O. \& Sales O. Jr. 2000: Morphological Aspects of the Egg, $1^{\text {st }}$ and $5^{\text {th }}$ Nymphal Instars of the Burrowing Bug, Atarsocoris brachiariae Becker, 1996 (Hemiptera. Cydnidae). XXI International Congress of Entomology, Brazil, August 20-26, 2000, Abstract Book II, Session 16 - Morphology and ultrastructure, $797 \mathrm{pp}$.

MoIZUDDIN M. \& AHMAD I. 1985: Eggs and nymphal systematics of Macroscytus subaeneus (Dallas) (Pentatomoidea: Cydnidae) of Pakistan with reference to phylogeny. Kar. Univ. J. Sci. 13: 163-169.

PAUL A.R. 1953: Life history of the pied shield bug Sehirus bicolor L. (Hem.: Cydnidae). Entomol. Mon. Mag. 89: 210-211.

Putshrov V.G. 1961: Shield-bugs (Hemiptera, Pentatomoidea) Fauna of Ukraine 21: 1-338 [in Ukrainian].
Putshriova L.V. 1959: Morphological assay of the head in Pentatomoidea (Hemiptera-Heteroptera). Zool. Zhurn. 38: 1825-1834 [in Russian].

SCHAEFER C.W. 1975: Heteropteran trichobothria (Hemiptera: Heteroptera). Int. J. Insect Morphol. \& Embryol. 4: 193-264.

SCHORR H. 1957: Zur Verhaltensbiologie und symbiose von Brachypelta aterrima Forst. (Cydnidae, Heteroptera). Z. Morphol. Ökol. Tiere 45: 561-602.

Scruor R. T. 1975: The structure, distribution, and taxonomic importance of trichobothria in the Miridae (Hemiptera). Am. Mus. Novit. 2585: 1-26.

Signoret V. 1881: Révision du Groupe des Cydnides de la Famille des Pentatomides. 1re partie. Annls Soc. Entomol. Fr. (Ser. 6) 1: 25-52.

SouTHWOOD T.R.E. 1949: Some notes on the early stages and biology of Sehirus bicolor L. (Hem.: Cydnidae). Entomol. Mon. Mag. 85: 39-41.

Thomas D.B. 1988: Fossil Cydnidae (Heteroptera) from OligoMiocene amber of Chiapas, Mexico. J. New York Entomol. Soc. 96: 26-29.

WILBRINK G. 1912: De Kederische Wortelwants. Stibaropus molginus (Schiodt). Mededeel. Proefstat. Java-Suikerind. 22: 639-651.

Received April 10, 2001; revised October 16, 2001; accepted December 7, 2001 


\section{BOOK REVIEW}

TABER S.W.: FIRE ANTS. Texas A\&M University Press, 2000, 308 pp., hard cover, ISBN 0-89096-945-0. Price 29.95 USD.

In the southern parts of the United States of America there is a problem - the fire ants. They do not cause "fires", but sting (it is not bite!) which because it provokes in humans a painful burning sensations, earned these insects their common name Two species are involved - the first, "black imported ant" (Solenopsis invicta, the species name of which means "invincible") arrived in the USA in 1915, the second, "red imported ant" (Solenopsis richteri) between 1933 and 1945. Both came from South America probably by ship, and each species may have arrived on more than one occasion. The second species is the more important. Its fiery aggression, voracious feeding, and prolific nest building combined to make this species a pest of many field crops, e.g., cotton, potatoes, cucumbers, tomatoes, cabbage etc., and also orchards and pastures. They are omnivorous, eating both animal and vegetable, and catching not only various insects and other invertebrates, but also vertebrates such as young rabbits, rats, and mice. (It is said that they can kill calves and piglets!) Being stung hundred of sensitive people die every year in an anaphyletic shock

There is an immense literature about these ants and Stephen Taber, who teaches at St. Edward's University, Austin (Texas), is the first to put all this infomation together in one book. And he has succeeded! In 14 chapters he discusses all six species of ants from the genus Solenopsis, not just the two introduced species, the origin and evolution of fire ants, their symbionts, medical importance, chemical control, and the pros and cons of their enemies in the context of biocontrol. (The fire ants are not only nuisance, but also beneficial as they kill other banes, including larvae of horn and stable flies and lone star ticks!). The book has three appendixes - fire ants of the world, how to identify U.S. fire ants and how to preserve fire ants for study, and concludes with a glossary, detailed bibliography and index. It is a very good book. People interested in fire ants will appreciate this book very much.

J.Chalupský 